\title{
The role of high-socioeconomic-status people in locking in or rapidly reducing energy-driven greenhouse gas emissions
}

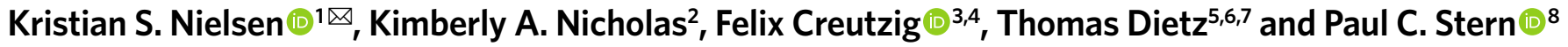

People with high socioeconomic status disproportionally affect energy-driven greenhouse gas emissions directly through their consumption and indirectly through their financial and social resources. However, few climate change mitigation initiatives have targeted this population segment, and the potential of such initiatives remains insufficiently researched. In this Perspective, we analyse key characteristics of high-socioeconomic-status people and explore five roles through which they have a disproportionate impact on energy-driven greenhouse gas emissions and potentially on climate change mitigation, namely as consumers, investors, role models, organizational participants and citizens. We examine what is known about their disproportionate impact via consumption and explore their potential influence on greenhouse gas emissions through all five roles. We suggest that future research should focus on strategies to reduce greenhouse gas emissions by high-socioeconomic-status people and to align their investments, organizational choices and actions as social and political change agents with climate change mitigation goals.
\end{abstract}

A rapid transition to fossil-free energy is required to stabilize the climate system within the Paris Agreement temperature targets ${ }^{1}$, but the best strategies for achieving this transition remain under debate. Some researchers argue that behaviour change by individual consumers to reduce energy consumption can make a meaningful and timely contribution and that such actions may be essential for successfully motivating and achieving systemic change ${ }^{2-4}$. Well-designed initiatives to reduce energy-intensive consumption while improving infrastructure and providing community-based services ${ }^{5,6}$ are part of the steep decarbonization pathways modelled in Intergovernmental Panel on Climate Change (IPCC) assessments ${ }^{1}$. Others argue that reducing personal energy consumption has little effect ${ }^{7,8}$ and that the promotion of individual action by the fossil fuel industry is intended to shift responsibility from fossil fuel producers to individual consumers, thus delaying meaningful climate policy ${ }^{9,10}$.

In this Perspective, we broaden the debate beyond the role of individuals as consumers to consider other social roles. We focus on individuals and households with high socioeconomic status (SES; henceforth, high-SES people) because they have generated many of the problems of fossil fuel dependence that affect the rest of humanity. The disproportionate share of fossil energy use and energy-intensive consumption by high-SES people is well known ${ }^{11,12}$ and has been the focus of the bulk of available research on SES and greenhouse gas (GHG) emissions ${ }^{13}$.

SES is a composite concept that refers to an individual's position in the structure of a society. SES reflects access to both financial and social resources and includes social class. For example, people classified as capitalists, who are mainly high in SES, are those who receive a large fraction of their incomes from investments rather than labour. High-SES people control a highly disproportionate fraction of financial resources: income and wealth ${ }^{14}$. Income is the net flow of financial resources into a household over time; wealth is the stock of accumulated capital resources. Other aspects of SES, such as occupational status and residential neighbourhood quality, which are less easily measured, reflect social resources ${ }^{15}$ and affect energy use and GHG emissions through actions other than consumption $^{16}$.

Here, we argue that high-SES people, who by many criteria include the authors and many readers of this analysis, are well positioned to influence the actions of other individuals, organizations and political systems. In addition to their high GHG emissions from consumption, high-SES people have disproportionate climate influence through at least four non-consumer roles: as investors, as role models within their social networks and for others who observe their choices, as participants in organizations and as citizens seeking to influence public policies or corporate behaviour (Fig. 1). Through these roles, they help shape the choices available to themselves and others. We examine the ways high-SES people, acting via these five roles, affect GHG emissions by influencing personal or organizational actions that promote, incentivize or reduce fossil fuel production and consumption. We propose three directions for future research to investigate ways high-SES people might use their five roles to leverage climate change mitigation.

\section{Identification of high-SES people}

Although all components of SES may affect an individual's potential to contribute to climate change mitigation, much of the available research focuses on income, which is strongly correlated with other SES indicators and is easily measurable. When we consider income as a variable to identify high-SES people, we focus primarily on people in the top $1 \%$ of income globally (around US\$109,000

'Department of Psychology, University of Cambridge, Cambridge, UK. ${ }^{2}$ Centre for Sustainability Studies, Lund University, Lund, Sweden. ${ }^{3}$ Mercator Research Institute on Global Commons and Climate Change, Berlin, Germany. ${ }^{4}$ Sustainability Economics of Human Settlements, Technical University Berlin, Berlin, Germany. ${ }^{5}$ Department of Sociology, Michigan State University, East Lansing, MI, USA. ${ }^{6}$ Environmental Science and Policy Program, Michigan State University, East Lansing, MI, USA. ${ }^{7}$ Gund Institute for Environment, University of Vermont, Burlington, VT, USA. ${ }^{8}$ Social and Environmental Research Institute, Shelburne Falls, MA, USA.凶e-mail: ksn27@cam.ac.uk 


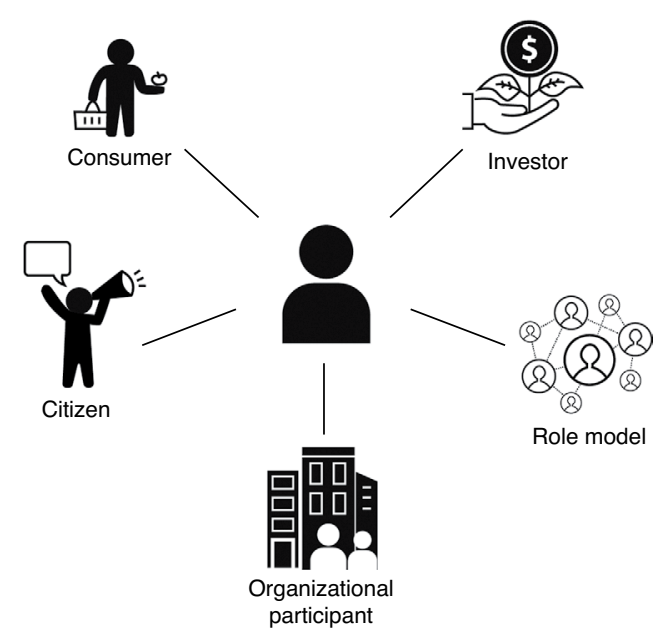

Fig. 1 | Five roles through which people of high SES can influence GHG emissions. People with high SES have disproportionate climate influence via their roles as consumers, investors, role models within their social networks and for others who observe their choices, participants in organizations and citizens seeking to influence public policies or corporate behaviour. Image credit: Emma Li Johansson (Lilustrations) and the Noun Project (https://thenounproject.com/)

$\left(\right.$ refs. $\left.\left.{ }^{6,17}\right)\right)$. We concentrate on Europe and North America, where the most evidence is available and where the majority of the global top $1 \%$ of income live ${ }^{18}$. For example, in $2012,37 \%$ of the global top $1 \%$ of income lived in the United States, $7.1 \%$ in Germany and $5.4 \%$ in France $^{18}$. We also consider non-income aspects of SES when data are available. However, identifying the top $1 \%$ is more difficult for social resources such as occupational status or access to political influence, where relative standing within a country or community may matter more than global standing.

Consumption by high-SES people produces far more GHG emissions than that of their lower-SES counterparts. People in the global top $1 \%$ of income cause twice as much consumption-based $\mathrm{CO}_{2}$ emissions as those in the bottom $50 \%$ (15\% versus $7 \%$, respectively $)^{17}$. Accurate analyses of emissions from the top $0.1 \%$ are scarce due to their under-representation in national and global analyses, in part because they are notoriously difficult to recruit for survey-based research ${ }^{19}$. However, many ultra-high-net-worth individuals with assets over US $\$ 50$ million have exceptionally large climate footprints through consumption, including owning multiple dwellings and using private jets ${ }^{20}$. Overall, those in the top $10 \%$ of income globally are responsible for $40-60 \%$ of total GHG emissions ${ }^{11,12}$. These striking inequalities in GHG emissions from consumption, along with the disproportionate influence of high-SES people acting as investors, role models, organizational participants and citizens, as discussed below, marks these people as major drivers of climate change and justifies our focus on this population segment. Variations within and across countries in the actions of the top $10 \%$ and the top $1 \%$ also deserve investigation.

The impacts of climate change are also disproportionate High-SES people emit the most GHGs but tend to be least vulnerable to the adverse effects of climate change ${ }^{21}$, whereas lower-SES people are typically most vulnerable. Lower-SES people also tend to be most adversely affected by mitigation policies ${ }^{22,23}$, although good policy design can prevent regressive impacts ${ }^{10}$. In addition, inequalities within countries, particularly of income and wealth, appear to exacerbate GHG emissions and compromise sustainability ${ }^{24}$. This is likely due both to consumption by high-SES people and to the kinds of policies and political positions many of them support ${ }^{25}$. We recognize important climate justice concerns that follow from the disproportionality of both responsibility and impacts. Here, we focus on potential leverage points for mitigation through the decisions and actions by high-SES people within five social roles.

\section{Consumer}

Actual GHG emissions reductions achieved through changes in consumption depend on the product of the technical potential of a change and behavioural plasticity ${ }^{2,26}$. The technical potential of actions, including adoption of a technology, refers to the emissions reductions that would be achieved if everyone took that action. Behavioural plasticity is the proportion of people who could be induced to take the action ${ }^{2}$. Behavioural plasticity depends on individual and household characteristics, the contexts of choices and initiatives that have been or might be undertaken to change behaviour ${ }^{4}$. Initiatives rarely achieve $100 \%$ uptake because target behaviours are not easily changed ${ }^{2}$ and/or because individuals and households respond differently than anticipated ${ }^{27}$. Even mandatory initiatives, such as bans on technology, take time to achieve full impact. Understanding behavioural plasticity among high-SES people, especially for consumer choices with high technical potential, is important because of the potential effects of these choices on aggregate energy use and GHG emissions. We briefly discuss technical potential and behavioural plasticity for three types of consumption that together represent the majority of high-SES people's GHG emissions: air travel, motor vehicle use and housing ${ }^{28}$.

Air travel. Air travel is the most energy-intensive consumer behaviour $^{29}$. Air travel emissions increase rapidly as a function of income ${ }^{30}$ and are the largest source of GHG emissions for high-emitting individuals, constituting over $40 \%$ of emissions for the top $1 \%$ of emitters in Europe ${ }^{28}$. Globally, air travel directly emits more $\mathrm{CO}_{2}$ than Germany does (2.4\% of global $\mathrm{CO}_{2}$ emissions), with high-altitude effects modelled as equivalent to $7.2 \%$ of global GHG emissions ${ }^{31}$. These emissions are overwhelmingly from high-SES people, with $50 \%$ of GHG emissions from air travel originating from just $1 \%$ of the world population ${ }^{30}$. Absent technological advances, the greatest technical potential for cutting GHG emissions from air travel lies in reducing its volume, particularly among frequent flyers.

High-SES people often lead hypermobile lives, travelling by air for private and work-related purposes induced by income, business travel paid for by employers and expectations associated with status, work and ownership of multiple homes ${ }^{20,32}$. Although the behavioural plasticity of air travel is under-researched ${ }^{33}$, it may be substantial for high-SES people given the likelihood that the marginal benefits of each flight are lower for them than for lower-SES people who may fly only rarely to visit family ${ }^{34}$. Changing social norms around hypermobility therefore appear to be an important potential lever to decrease GHG emissions from air travel ${ }^{35}$. Increasing experience with remote meetings may also reduce demand for business travel ${ }^{36}$.

Motor vehicle use. Motor vehicles are the largest source of per capita GHG emissions in the United States ${ }^{37}$ and the second-largest source in Europe, where they are responsible for $21 \%$ of personal GHG emissions among the top $1 \%$ of emitters ${ }^{28}$. Emissions from motor vehicles are highly correlated with income ${ }^{11}$ and come overwhelmingly from private vehicle use ${ }^{38}$. These GHG emissions are affected by vehicle ownership, fuel economy and distance travelled. The largest technical potential for reducing emissions comes from a modal shift from private vehicles to transit, walking and biking ${ }^{29}$. Estimates of the technical potential of substituting non-fossil vehicles (for example, battery electric vehicles) for internal combustion vehicles vary but will increase as electric grids decarbonize ${ }^{29}$. The technical potential of changing the use of vehicles, such as sharing vehicles or driving more fuel efficiently, is about six times smaller than that of switching to electric vehicles, on average ${ }^{29}$. 
Behavioural plasticity for reducing motor vehicle emissions has received relatively little study, particularly as a function of income. Limiting warming well below $2{ }^{\circ} \mathrm{C}$ will require policies to reduce vehicle ownership and usage, along with a transition to electric vehicles running on zero-carbon energy ${ }^{39}$. High-income people are likely to lead this transition because they are the primary purchasers of new vehicles, with spillover effects over time into the used vehicle market and through more widespread availability of electric-vehicle charging stations.

However, vehicle use also strongly depends on infrastructure availability and status. Infrastructure that favours motor vehicles greatly increases vehicle use $\mathrm{e}^{40}$. Allocating street space for pedestrians and cyclists, an element of economic fairness ${ }^{41}$, favours non-motorized travel ${ }^{42}$.

Ownership of high-emissions vehicles is correlated with income but may also be a sign of aspiration for social status ${ }^{43}$. High-SES people can lead mitigation through shifting social norms from valuing private vehicle ownership and use $\mathrm{e}^{44}$ to valuing living in walkable neighbourhoods and bicycling or using other low-emissions travel options.

During the current COVID-19 pandemic, the largest share of GHG emissions reductions has come from reduced land travel, although after a large initial drop, these emissions rebounded to close to their prepandemic levels ${ }^{45}$. The initial reduction likely occurred disproportionately among high-SES people because they have more GHG emissions to reduce and because they are more likely to do work that can be performed remotely.

Housing. In Europe, nearly 11\% of GHG emissions from housing come from the top $1 \%$ of emitters ${ }^{28}$, whose emissions are attributable to ownership and occupancy of larger homes, multiple residences and highly energy-consuming household goods such as central air conditioning. High SES may also drive housing-related emissions because attractive public amenities, such as parks and high-quality schools, are often located in communities featuring large homes ${ }^{3}$. High income may also enable reduced GHG emissions through housing actions with high up-front costs such as home retrofits ${ }^{46}$ and adoption of residential solar panels ${ }^{47}$. The highest technical potential for reducing emissions from housing comes from switching to renewable energy, followed by large-scale renovations and updating household equipment's energy efficiency ${ }^{29}$. Well-designed public policies can make these actions available to lower-income households as well ${ }^{48}$.

Regarding behavioural plasticity, most studies have unfortunately focused on behaviours with relatively low technical poten$\mathrm{tial}^{4}$, so much less is known about costly and high-potential actions. Available evidence is mixed as to the effects of SES. For example, a recent study using nationally representative data from 22 European countries found that income and education were negatively correlated with curtailing energy use but positively correlated with energy efficiency actions ${ }^{49}$. Other studies find that high-SES people more often invest in energy-efficient technologies ${ }^{50,51}$. Because home energy efficiency improvements typically achieve greater GHG emissions reductions in practice than do curtailments ${ }^{2}$, the evidence on balance suggests that income is positively correlated with the potential to reduce emissions. Mitigation policies can have differential effects as a function of income. Historically, a carbon tax has had little impact on the consumption of high-income households because it is a negligible change in their budget compared with the much larger and more burdensome effects on low-income households ${ }^{52,53}$. Other financially focused policies, such as reducing up-front costs, can have less economically regressive effects.

The location of high-status housing may either reduce or increase GHG emissions, depending on whether it lies in dense, expensive city centres with smaller housing units or in suburban areas with large homes and lots, which have emissions nearly twice as high, primarily from greater reliance on motor vehicles to travel longer distances ${ }^{54}$. Because housing choices signify prestige and social status, high-SES people may resist change unless social norms also change, as discussed in the section on role modelling.

We emphasize that much consumer behaviour, and indeed the other behaviours we discuss below, is influenced not only by rational choice but by numerous other factors including routines, normative influences, and heuristics and biases. This suggests that while prices may be one path to influencing consumer decisions, strategies based on norms or on changing default choices and otherwise breaking routines can also be highly effective ${ }^{4,55}$, amplifying the importance of high-SES people as role models.

\section{Investor}

Investments in stocks, bonds, businesses and real estate are disproportionately made by those in the top $1 \%$ of income and wealth ${ }^{56}$. Through shifting investments to low-emissions companies and mutual funds, high-SES people can press companies to lower GHG emissions and thereby drive structural change $\mathrm{e}^{57}$. By contrast, investments that favour continuing fossil fuel use will delay emissions reductions.

Anti-fossil-fuel investment norms are being promoted by a movement to push the private sector to divest from fossil fuels and reinvest in lower-emissions securities. The organizational leaders in the divestment and reinvestment movement have mainly been elite universities, church groups and some public pension funds ${ }^{57}$. High-SES people may influence these organizations through their informal contacts and their presence on governing boards, to either embrace or resist the efforts of social movements promoting investment shifts. Further signs of shifting norms include the rise of climate-related investment funds to meet the emerging demands of individual investors and organizations (with offerings in Europe increasing about $80 \%$ from 2018 to 2020 (ref. ${ }^{58}$ )) and a new European Union regulation requiring asset managers to disclose how they consider sustainability factors in their investment advice ${ }^{59}$. Low-emissions funds also increase behavioural plasticity by reducing the information costs to investors of identifying low-emissions securities. Efforts to support climate-compatible investing need to more narrowly target the highest-income investors, who control a large portion of the market and to date have been slow to change or in some cases actively resisted such changes ${ }^{57}$.

\section{Role model}

High-SES people have driven increased emissions in the past but can also contribute to mitigation via their positions as role models within their social networks and for those who aspire to their levels of status. Their influence comes through their social networks with other high-SES people and by shaping societal and cultural conceptions of 'the good life' and related social norms ${ }^{3}$. For example, the popularity of hybrid and then all-electric vehicles was amplified by celebrities adopting and promoting them ${ }^{60}$. Veganism has also gained popularity among some high-SES people and has been popularized by events such as the all-vegan Golden Globe award ceremony in January 2020. These phenomena illustrate how highSES people can play a central role in diffusing new low-emissions technologies and behaviours ${ }^{3,61}$, although effects may vary across contexts $^{62}$. High-SES people can, of course, also reinforce the status quo by acting as role models for conspicuous consumption practices $^{63}$ that counteract the diffusion of more sustainable norms and slow mitigation.

High-SES people can shape the discourse on climate change via their financial and social support for political campaigns, think tanks and research institutes ${ }^{64}$ and their ties to influential entities such as elite universities and corporate and non-profit boards. While there are divisions within these entities, their overall influence is immense, both through the creation and diffusion of norms within 


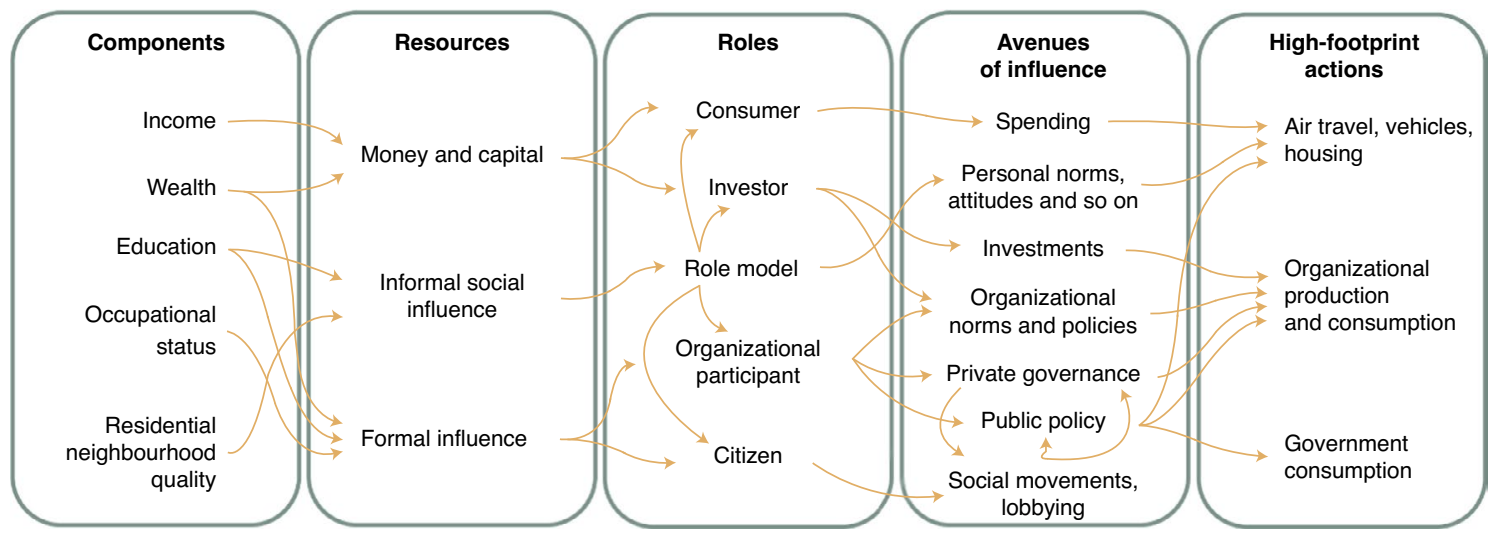

Fig. 2 | Links from SES to actions with high climate footprints. The silos depict how components of SES ${ }^{15}$ and the resources they provide may influence high-footprint actions via five social and financial roles that operate through different avenues of influence. The arrows in the figure represent links we hypothesize as important; the figure as a whole and the hypothesized links suggest an agenda for future research. Image credit: Emma Li Johansson (Lilustrations).

these elite spaces and the influence of their wealth and informal connections on politics, as discussed below. Of course, mitigation policies can produce winners and losers, and high-SES people can also use their power to shape mitigation efforts to their advantage ${ }^{65}$.

\section{Organizational participant}

By virtue of occupational status, high-SES people disproportionally influence organizations' GHG emissions directly through occupying positions such as owner, manager, board member, employee and consultant, and indirectly influence the emissions of their suppliers, customers and competitors. On average, those who achieve leadership in private organizations begin with an SES advantage. For example, top-level officials in Fortune 500 companies disproportionally come from elite colleges and universities, have attended high-prestige private secondary schools and still, despite diversity efforts, are predominantly male and white ${ }^{66}$.

In recent years, many private organizations have taken leadership in reducing GHG emissions, for example, by enacting climate targets, goals or procurement policies for supply chain decarbonization. This private climate governance by organizations and institutions, including businesses, is making more progress towards emissions reduction in some countries than public policy and may pave the way for public governance initiatives ${ }^{67}$. Businesses are also developing and marketing low-emissions products and creating carbon-labelling programs, sometimes acting ahead of governments ${ }^{67,68}$. Elite individuals also engage in climate philanthropy, either through creating their own organizations or supporting others, such as the international C40 climate network built with the personal fortune of a former New York City mayor ${ }^{69}$ (although the role of elite philanthropy in climate change mitigation is controversial ${ }^{70}$ ).

Little research exists, however, on the extent to which the potential for harnessing organizational change is achieved through actions by high-SES people or could be enhanced by initiatives targeting them (see, however, the literature ${ }^{71}$ for the role of professionals). As the most elite members of society derive their income largely from investments, they can also be sources of resistance to climate reforms when they perceive these reforms as threatening their status or profits.

\section{Citizen}

People can affect GHG emissions at the system level via influencing public policies by voting, lobbying and participating in social movements. Globally and in most countries, the social networks of the top $0.1 \%$ are at the core of political and economic power ${ }^{64}$.
High-SES people can have a disproportionate impact in the citizen role through their greater access to decision makers in private organizations and in the public sector. Their financial resources also advantage them because contributions to lobbying groups, political office holders and social movement organizations increase their access and influence among these groups, giving them an easier path to advancing or blocking social change ${ }^{72}$.

Lobbying has a strong influence on energy-related public policy ${ }^{73,74}$. Whether people lobby directly or through their roles in private or non-profit organizations, the greatest influence comes from small numbers of highly influential people ${ }^{64}$. Citizen action by elites has previously been a strong force against mitigating climate change, but it could become a substantial force for mitigation. In the energy sector, lobbying and public messaging has come overwhelmingly from the fossil fuel sector and favoured policies that entrench fossil fuel production and consumption ${ }^{9}$. For example, two fossil fuel billionaires, acting over decades, had a profound influence in shifting the policy discourse in the United States to the right, including the ascendency of politicians favouring low taxes, opposed to environmental protection and climate action, and mistrustful of government overall ${ }^{75,76}$. While renewable energy firms and others who can profit from a transition to a low-carbon future could in theory counter these influences, their impacts so far appear minimal ${ }^{74}$.

\section{Conclusions and research directions}

High-SES people make a disproportionate contribution to energydriven GHG emissions in many ways. Their influence via consumption has received the most research attention, but as Fig. 2 indicates, they can also have an outsized influence on emissions and climate change mitigation in non-consumer roles by leveraging the substantial financial and social resources associated with different components of their status. Figure 2 identifies several avenues of influence through which high-SES people, by employing these resources within these roles, can affect actions with large climate footprints. Many mitigation opportunities suggested by the figure have been insufficiently explored in research and policy.

We highlight three main gaps in knowledge about climate change mitigation that can be addressed by research focused on high-SES people. One is the behavioural plasticity of their consumption, especially with regard to air travel, motor vehicles and housing. Some initiatives to reduce high-SES people's GHG emissions can also protect vulnerable groups ${ }^{77,78}$. For example, Gössling and Humpe ${ }^{30}$ describe the current lack of markets for the negative externalities caused by air travel as a major subsidy to the most affluent, since the top $1 \%$ of the global population accounts for half of associated 
GHG emissions. However, a linear pricing mechanism, such as a carbon tax, may be less effective among the wealthy than a frequent flyer levy with a progressive tax on frequent air travel. The latter approach also receives more support in international polling than tax options ${ }^{79}$. Progressive taxation on high incomes or on substantial wealth may be particularly beneficial to the climate, as it reduces status consumption while keeping relative status and related subjective well-being unchanged ${ }^{80}$. Wealth taxes might also reduce inequality by reducing the influence of the most elite, who now dominate the policy system. All these possibilities warrant further analysis for their effect on GHG emissions, as does the study of non-financial behaviour change interventions to change high-emissions consumer actions specific to high-SES people ${ }^{4}$.

A second research gap concerns the role of high-SES people in organizations. An important empirical question is how these people are enabled or limited in changing organizational culture and business decisions to reduce GHG emissions. A committed individual or small group can change a business culture and investments (a strategy being pursued by an activist investor on the board of Exxon). Currently, little is known about what factors support such disruptive action or about the responsiveness of private organizations to initiatives by high-SES people within and outside them (for example, major suppliers and customers, or critical employees). Such research could inform initiatives for organizational change.

A third gap is in understanding how high-SES people influence policy processes through their political capital, organizational influence and financial contributions to lobbying and electoral campaigns. High-SES people have benefitted most from current policies and the structure of the political economy, and there is some evidence that altruism declines with affluence ${ }^{72,81}$. We need to understand differences among high-SES people in how they use their influence on policy and politics and on organizational actions to promote or obstruct rapid decarbonization ${ }^{82}$, as well as how they might be induced to use their influence to promote it. Meanwhile, increasing political participation, representation and power for currently under-represented groups would help reduce both political and climate inequalities.

In conclusion, we stress that high-SES people are disproportionately responsible for causing climate change and its harms. The same roles that generated this responsibility also offer high-leverage opportunities for reducing GHG emissions and thus climate damages. We also acknowledge that important approaches to climate change mitigation emerge from those not high in SES, including local and indigenous solutions, but our focus here is on those who have generated most of the problem. No single strategy alone can 'solve' the climate problem, but the actions of high-SES people can have a great impact, so further research and discussion of strategies for changing their (our) actions are certainly warranted.

Received: 26 February 2021; Accepted: 30 July 2021; Published online: 30 September 2021

\section{References}

1. IPCC, 2018: Summary for Policymakers. In Global Warming of $1.5^{\circ} \mathrm{C}$. An IPCC Special Report on the impactsof global warming of $1.5^{\circ} \mathrm{C}$ above pre-industrial levels and related global greenhouse gas emission pathways, in the context of strengthening the global response to the threat of climate change, sustainable development, and efforts to eradicate poverty (eds Masson-Delmotte, V. et al.) In Press.

2. Dietz, T., Gardner, G. T., Gilligan, J., Stern, P. C. \& Vandenbergh, M. P. Household actions can provide a behavioral wedge to rapidly reduce US carbon emissions. Proc. Natl Acad. Sci. USA 106, 18452-18456 (2009).

3. Frank, R. H. Under the Influence: Putting Peer Pressure to Work (Princeton Univ. Press, 2020).

4. Nielsen, K. S. et al. How psychology can help limit climate change. Am. Psychol. 76, 130-144 (2021)

5. Creutzig, F. et al. Beyond technology: demand-side solutions for climate change mitigation. Annu. Rev. Environ. Resour. 41, 173-198 (2016).
6. Capstick, S. et al. UNEP Emissions Gap Report 2020; 62-75 (UNEP, 2020) https://wedocs.unep.org/handle/20.500.11822/34432

7. York, R. Environmental consequences of moral disinhibition. Socius https://doi.org/10.1177/2378023117719612 (2017).

8. Werfel, S. H. Household behaviour crowds out support for climate change policy when sufficient progress is perceived. Nat. Clim. Change 7, 512-515 (2017)

9. Supran, G. \& Oreskes, N. Assessing ExxonMobil's climate change communications. Environ. Res. Lett. 12, 084019 (2017).

10. Lamb, W. F. et al. Discourses of climate delay. Glob. Sustain. https://doi.org/ 10.1017/sus.2020.13 (2020).

11. Oswald, Y., Owen, A. \& Steinberger, J. K. Large inequality in international and intranational energy footprints between income groups and across consumption categories. Nat. Energy 5, 231-239 (2020).

12. Chancel, L. \& Piketty, T. Carbon and Inequality: from Kyoto to Paris (Paris School of Economics, 2015) http://piketty.pse.ens.fr/files/ChancelPiketty2015.pdf

13. Wiedmann, T., Lenzen, M., Keyßer, L. T. \& Steinberger, J. K. Scientists' warning on affluence. Nat. Commun. 11, 3107 (2020).

14. Wright, E. O. Understanding Class (Verso Books, 2015).

15. Farah, M. J. The neuroscience of socioeconomic status: correlates, causes, and consequences. Neuron 96, 56-71 (2017).

16. Campbell, K. E., Marsden, P. V. \& Hurlbert, J. S. Social resources and socioeconomic status. Soc. Netw. 8, 97-117 (1986)

17. Kartha, S., Kemp-Benedict, E., Ghosh, E., Nazareth, A. \& Gore, T. The Carbon Inequality Era: an Assessment of the Global Distribution of Consumption Emissions among Individuals from 1990 to 2015 and Beyond (Stockholm Environment Institute and Oxfam International, 2020) https://policy-practice. oxfam.org/resources/the-carbon-inequality-era-an-assessment-of-the-globaldistribution-of-consumpti-621049/

18. Anand, S. \& Segal, P. Who are the global top 1\%? World Dev. 95, 111-126 (2017)

19. Ravallion, M. Missing Top Income Recipients Working Paper No. 28890 (National Bureau of Economic Research, 2021) https://www.nber.org/papers/ w28890

20. Gössling, S. Celebrities, air travel, and social norms. Ann. Tour. Res. 79, 102775 (2019)

21. Boyce, J. K. Inequality as a cause of environmental degradation. Ecol. Econ. 11, 169-178 (1994)

22. Dietz, T., Shwom, R. L. \& Whitley, C. T. Climate change and society. Annu. Rev. Sociol. 46, 135-158 (2020).

23. Robinson, M. \& Shine, T. Achieving a climate justice pathway to $1.5^{\circ} \mathrm{C}$ Nat. Clim. Change 8, 564-569 (2018).

24. Knight, K. W., Schor, J. B. \& Jorgenson, A. K. Wealth inequality and carbon emissions in high-income countries. Soc. Curr. 4, 403-412 (2017).

25. McCright, A. M., Marquart-Pyatt, S. T., Shwom, R. L., Brechin, S. R. \& Allen, S. Ideology, capitalism, and climate: explaining public views about climate change in the United States. Energy Res. Soc. Sci. 21, 180-189 (2016).

26. Nielsen, K. S. et al. Improving climate change mitigation analysis: a framework for examining feasibility. One Earth 3, 325-336 (2020).

27. Hanna, R., Duflo, E. \& Greenstone, M. Up in smoke: the influence of household behavior on the long-run impact of improved cooking stoves. Am. Econ. J. Econ. Policy 8, 80-114 (2016).

28. Ivanova, D. \& Wood, R. The unequal distribution of household carbon footprints in Europe and its link to sustainability. Glob. Sustain. 3, e18 (2020)

29. Ivanova, D. et al. Quantifying the potential for climate change mitigation of consumption options. Environ. Res. Lett. 15, 093001 (2020).

30. Gössling, S. \& Humpe, A. The global scale, distribution and growth of aviation: implications for climate change. Glob. Environ. Change 65, 102194 (2020).

31. Lee, D. S. et al. The contribution of global aviation to anthropogenic climate forcing for 2000 to 2018. Atmos. Environ. 244, 117834 (2021).

32. Litman, T. in Car Troubles: Critical Studies of Automobility and Auto-mobility (eds McLaren, A. T. \& Conley, J.) 199-218 (Ashgate Publishing, 2009).

33. Wynes, S., Nicholas, K. A., Zhao, J. \& Donner, S. D. Measuring what works: quantifying greenhouse gas emission reductions of behavioural interventions to reduce driving, meat consumption, and household energy use. Environ. Res. Lett. 13, 113002 (2018)

34. Gössling, S., Hanna, P., Higham, J., Cohen, S. \& Hopkins, D. Can we fly less? Evaluating the 'necessity' of air travel. J. Air Transp. Manag. 81, 101722 (2019)

35. Oswald, L. \& Ernst, A. Flying in the face of climate change: quantitative psychological approach examining the social drivers of individual air travel. J. Sustain. Tour. 29, 68-86 (2020).

36. Baert, S., Lippens, L., Moens, E., Weytjens, J. \& Sterkens, P. The COVID-19 Crisis and Telework: a Research Survey on Experiences, Expectations and Hopes IZA Discussion Paper No. 13229 (SSRN, 2020) https://papers.ssrn.com/sol3/ papers.cfm?abstract_id=3596696

37. Jones, C. \& Kammen, D. M. Quantifying carbon footprint reduction opportunities for U.S. households and communities. Environ. Sci. Technol. 45, 4088-4095 (2011). 
38. Ahmad, S. \& Creutzig, F. Spatially contextualized analysis of energy use for commuting in India. Environ. Res. Lett. 14, 45007 (2019).

39. Milovanoff, A., Posen, I. D. \& MacLean, H. L. Electrification of light-duty vehicle fleet alone will not meet mitigation targets. Nat. Clim. Change 10, 1102-1107 (2020).

40. Hymel, K. M., Small, K. A. \& Van Dender, K. Induced demand and rebound effects in road transport. Transp. Res. B Methodol. 44, 1220-1241 (2010).

41. Creutzig, F. et al. Fair street space allocation: ethical principles and empirical insights. Transp. Rev. 40, 711-733 (2020).

42. Heinen, E., Harshfield, A., Panter, J., Mackett, R. \& Ogilvie, D. Does exposure to new transport infrastructure result in modal shifts? Patterns of change in commute mode choices in a four-year quasi-experimental cohort study. J. Transp. Heal. 6, 396-410 (2017).

43. Ramakrishnan, A., Kalkuhl, M., Ahmad, S. \& Creutzig, F. Keeping up with the Patels: conspicuous consumption drives the adoption of cars and appliances in India. Energy Res. Soc. Sci. 70, 101742 (2020).

44. Mattioli, G., Roberts, C., Steinberger, J. K. \& Brown, A. The political economy of car dependence: a systems of provision approach. Energy Res. Soc. Sci. 66 101486 (2020).

45. Liu, Z. et al. Near-real-time monitoring of global $\mathrm{CO}_{2}$ emissions reveals the effects of the COVID-19 pandemic. Nat. Commun. 11, 5172 (2020).

46. Kastner, I. \& Stern, P. C. Examining the decision-making processes behind household energy investments: a review. Energy Res. Soc. Sci. 10, 72-89 (2015).

47. Bollinger, B., Gillingham, K. T. \& Ovaere, M. Field experimental evidence shows that self-interest attracts more sunlight. Proc. Natl Acad. Sci. USA 117, 20503-20510 (2020)

48. Fuller, M. C., Portis, S. C. \& Kammen, D. M. Toward a low-carbon economy: municipal financing for energy efficiency and solar power. Environ. Sci. Policy Sustain. Dev. 51, 22-33 (2009)

49. Umit, R., Poortinga, W., Jokinen, P. \& Pohjolainen, P. The role of income in energy efficiency and curtailment behaviours: findings from 22 European countries. Energy Res. Soc. Sci. 53, 206-214 (2019).

50. Ameli, N. \& Brandt, N. Determinants of households' investment in energy efficiency and renewables: evidence from the OECD survey on household environmental behaviour and attitudes. Environ. Res. Lett. 10, 044015 (2015).

51. Sardianou, E. \& Genoudi, P. Which factors affect the willingness of consumers to adopt renewable energies? Renew. Energy 57, 1-4 (2013).

52. Goulder, L. H., Hafstead, M. A. C., Kim, G. \& Long, X. Impacts of a carbon tax across US household income groups: what are the equity-efficiency trade-offs? J. Public Econ. 175, 44-64 (2019).

53. Boyce, J. K. Carbon pricing: effectiveness and equity. Ecol. Econ. 150, 52-61 (2018).

54. Baiocchi, G., Creutzig, F., Minx, J. \& Pichler, P. P. A spatial typology of human settlements and their $\mathrm{CO}_{2}$ emissions in England. Glob. Environ. Change 34, 13-21 (2015).

55. Wolske, K. S. \& Stern, P. C. in Psychology and Climate Change (eds Clayton, S. \& Manning, C.) 127-160 (Academic Press, 2018)

56. Alvaredo, F. The World Inequality Report (Harvard Univ. Press, 2018).

57. Mormann, F. Why the divestment movement is missing the mark. Nat. Clim. Change 10, 1067-1068 (2020).

58. Bioy, H. \& Stuart, E. Investing in Times of Climate Change: an Expanding Array of Choices for Climate-Aware Investors (Morningstar, 2020) https://www. morningstar.com/en-uk/lp/investing-in-times-of-climate-change

59. Moran, M., Treacy, J. \& Edey, G. Navigating the European ESG disclosure regime in a post-Brexit world. National Law Review https://www.natlawreview. $\mathrm{com} /$ article/navigating-european-esg-disclosure-regime-post-brexit-world (2021).

60. Ashmore, D. P., Pojani, D., Thoreau, R., Christie, N. \& Tyler, N. A. The symbolism of 'eco cars' across national cultures: potential implications for policy formulation and transfer. Transp. Res. D Transp. Environ. 63, 560-575 (2018).

61. Nyborg, K. et al. Social norms as solutions. Science 354, 42-43 (2016).

62. Rinscheid, A., Pianta, S. \& Weber, E. U. What shapes public support for climate change mitigation policies? The role of descriptive social norms and elite cues. Behav. Public Policy https://doi.org/10.1017/bpp.2020.43 (2020).
63. Veblen, T. The Theory of the Leisure Class: an Economic Study of Institutions (Allen and Unwin, 1899).

64. Domhoff, G. W. Studying the Power Elite: Fifty Years of Who Rules America? (Routledge, 2017).

65. Sovacool, B. K., Baker, L., Martiskainen, M. \& Hook, A. Processes of elite power and low-carbon pathways: experimentation, financialisation, and dispossession. Glob. Environ. Change 59, 101985 (2019).

66. Zweigenhaft, R. L. The role of elite education for white men, white women, and people of color in the US corporate elite. Who Rules America? https://whorulesamerica.ucsc.edu/power/elite_education.html (2021).

67. Vandenbergh, M. P. \& Gilligan, J. M. Beyond Politics (Cambridge Univ. Press, 2017).

68. Vandenbergh, M. P., Dietz, T. \& Stern, P. C. Time to try carbon labelling. Nat. Clim. Change 1, 4-6 (2011).

69. Acuto, M. \& Ghojeh, M. C40 cities inside out. Glob. Policy 10, 709-711 (2019).

70. Alberro, $\mathrm{H}$. Why billionaire climate philanthropists will always be part of the problem. The Conversation https://theconversation.com/why-billionaireclimate-philanthropists-will-always-be-part-of-the-problem-132383 (2020).

71. Parag, Y. \& Janda, K. B. Middle actors and socio-technical change in the energy system from the "middle-out". Energy Res. Soc. Sci. 3, 102-112 (2014)

72. Dietz, T. \& Whitley, C. T. Inequality, decisions, and altruism. Sociol. Dev. 4, 282-303 (2018).

73. Meng, K. C. \& Rode, A. The social cost of lobbying over climate policy. Nat. Clim. Change 9, 472-476 (2019).

74. Stokes, L. C. Short Circuiting Policy: Interest Groups and the Battle over Clean Energy and Climate Policy in the American States (Oxford Univ. Press, 2020).

75. Skocpol, T. \& Hertel-Fernandez, A. The Koch network and Republican party extremism. Perspect. Polit. 14, 681-699 (2016).

76. Mayer, J. Dark Money: the Hidden History of the Billionaires behind the Rise of the Radical Right (Anchor Books, 2017).

77. Owen, A. \& Barrett, J. Reducing inequality resulting from UK low-carbon policy. Clim. Policy 20, 1193-1208 (2020).

78. Newell, P., Daley, F. \& Twena, M. Changing Our Ways? Behaviour Change and the Climate Crisis (Cambridge Sustainability Commissions, 2021) https:/www.rapidtransition.org/resources/ cambridge-sustainability-commission/

79. Murray, L. Public Attitudes to Tackling Aviation's Climate Change Impacts (10:10 Climate Action, 2019)

80. Frank, R. H. Positional externalities cause large and preventable welfare losses. Am. Econ. Rev. 95, 137-141 (2005).

81. Mettler, S. \& SoRelle, M. in Theories of the Policy Process (eds Weible, C. M. \& Sabatier, P.) 103-134 (Routledge, 2018).

82. Seto, K. C. et al. Carbon lock-in: types, causes, and policy implications. Annu. Rev. Environ. Resour. 41, 425-452 (2016).

\section{Acknowledgements}

K.S.N. was supported by the Carlsberg Foundation, grant number CF20-0285. T.D. was supported by Michigan AgBio Research.

\section{Competing interests}

The authors declare no competing interests.

\section{Additional information}

Correspondence should be addressed to Kristian S. Nielsen.

Peer review information Nature Energy thanks Dario Kenner, Daniel Welch and the other, anonymous, reviewer(s) for their contribution to the peer review of this work.

Reprints and permissions information is available at www.nature.com/reprints. Publisher's note Springer Nature remains neutral with regard to jurisdictional claims in published maps and institutional affiliations.

(c) Springer Nature Limited 2021 